\title{
Novel Biomarkers in the Diagnosis of Benign and Malignant Gastrointestinal Diseases
}

\author{
Paulius Jonaitis Vytautas Kiudelis Greta Streleckiene Rolandas Gedgaudas \\ Jurgita Skieceviciene Juozas Kupcinskas \\ Department of Gastroenterology and Institute for Digestive Research, Lithuanian University of Health Sciences, \\ Kaunas, Lithuania
}

\section{Keywords}

Biomarkers · Gastrointestinal diseases - Genetic variations .

Microbiome · Micro-RNAs · Noncoding RNA · Cell-free DNA

\begin{abstract}
Background: Various noninvasive biomarkers have been used in the diagnosis, prognosis, and treatment of different gastrointestinal $(\mathrm{Gl})$ diseases for years. Novel technological developments and profound perception of molecular processes related to $\mathrm{Gl}$ diseases over the last decade have allowed researchers to evaluate genetic, epigenetic, and many other potential molecular biomarkers in different diseases and clinical settings. Here, we present a review of recent and most relevant articles in order to summarize major findings on novel biomarkers in the diagnosis of benign and malignant GI diseases. Summary: Genetic variations, noncoding RNAs (ncRNAs), cell-free DNA (cfDNA), and microbiomebased biomarkers have been extensively analyzed as potential biomarkers in benign and malignant GI diseases. Multiple single-nucleotide polymorphisms have been linked with a number of $\mathrm{Gl}$ diseases, and these observations are further being used to build up disease-specific genetic risk scores. Micro-RNAs and long ncRNAs have a large potential as non-
\end{abstract}

karger@karger.com www.karger.com/ddi

(c) 2021 S. Karger AG, Basel

Karger ${ }^{\prime \prime}=$ invasive biomarkers in the management of inflammatory bowel diseases and Gl tumors. Altered microbiome profiles were observed in multiple GI diseases, but most of the findings still lack translational clinical application. As of today, cfDNA appears to be the most potent biomarker for early detection and screening of Gl cancers. Key Messages: Novel noninvasive molecular biomarkers show huge potential as useful tools in the diagnostics and management of different $\mathrm{Gl}$ diseases. However, the use of these biomarkers in real-life clinical practice still remains limited, and further large studies are needed to elucidate the ultimate role of these potential noninvasive clinical tools.

(c) 2021 S. Karger AG, Basel

\section{Introduction}

Various biomarkers have been used in the diagnosis, prognosis, and treatment of different diseases $[1,2]$. Identification of high-risk individuals or early diagnosis of a disease is not only a part of primary prevention but also one of the main approaches in order to properly treat various conditions and increase overall survival (OS) $[3,4]$. Combination of benchmark diagnostic methods, such as 
evaluation of signs and symptoms, blood and other biomarkers, various medical imaging techniques, histopathology, microbiology, and surgical procedures, still remains the gold standard in the diagnostics of most pathologies. However, novel diagnostic approaches allow scientists to examine and evaluate each individual's genetic and epigenetic information in order to analyze disease susceptibility and tailor proper treatment for each patient $[5,6]$. This method is known as personalized medicine, which is expected to become the main therapeutic approach in the near future $[7,8]$. Various genetic variations are being investigated or are already used in the management of different diseases, such as type 1 diabetes [9-11], breast cancer [12-14], and Alzheimer's disease $[15,16]$. Gastroenterology is a field of medicine with a broad spectrum of disorders that have a big potential to be involved in genetic testing. A lot of effort is being put into research in order to discover these new biomarkers; however, the results are still controversial. Therefore, the aim of this review article is to summarize the findings of the most recent publications, studies, and information on the potential novel biomarkers (shown in Fig. 1) in the diagnosis of benign and malignant gastrointestinal (GI) diseases. All of the findings that are reviewed in this article are briefly summarized in Table 1 .

\section{Genetic Variations: SNPs and Genetic Risk Scores}

Latest advances in genomics allowed scientists to identify single-nucleotide polymorphisms (SNPs), which are the most frequent type of genetic variations in humans [17-19]. SNPs result from the variations of a single nucleotide in a DNA strand $[20,21]$. SNPs in genes that are responsible for cell cycle regulation, repair processes, and metabolism are associated with increased susceptibility to various types of cancer $[22,23]$. SNPs have also been linked with numerous benign and malignant GI diseases. Genome-wide association studies (GWASs) try to focus on associations between hundreds or thousands of SNPs and various diseases $[24,25]$.

One of the diseases that studies focus on is gastric cancer (GC). Some investigations found no relation between GC and multiple SNPs in various genes: polymorphisms of ACE, NOD1, TRL4, FAS/FASL [26] or IL1B, and IL$1 \mathrm{RN}$ [27] genes and SNPs of micro-RNAs (miRNAs) $-27 a,-146 a,-196 a-2,-492,-492 a$, and -608 [28] were not linked with higher risk of GC. However, other studies found some relations between gene polymorphisms and GC or premalignant gastric conditions. A study by Kup-

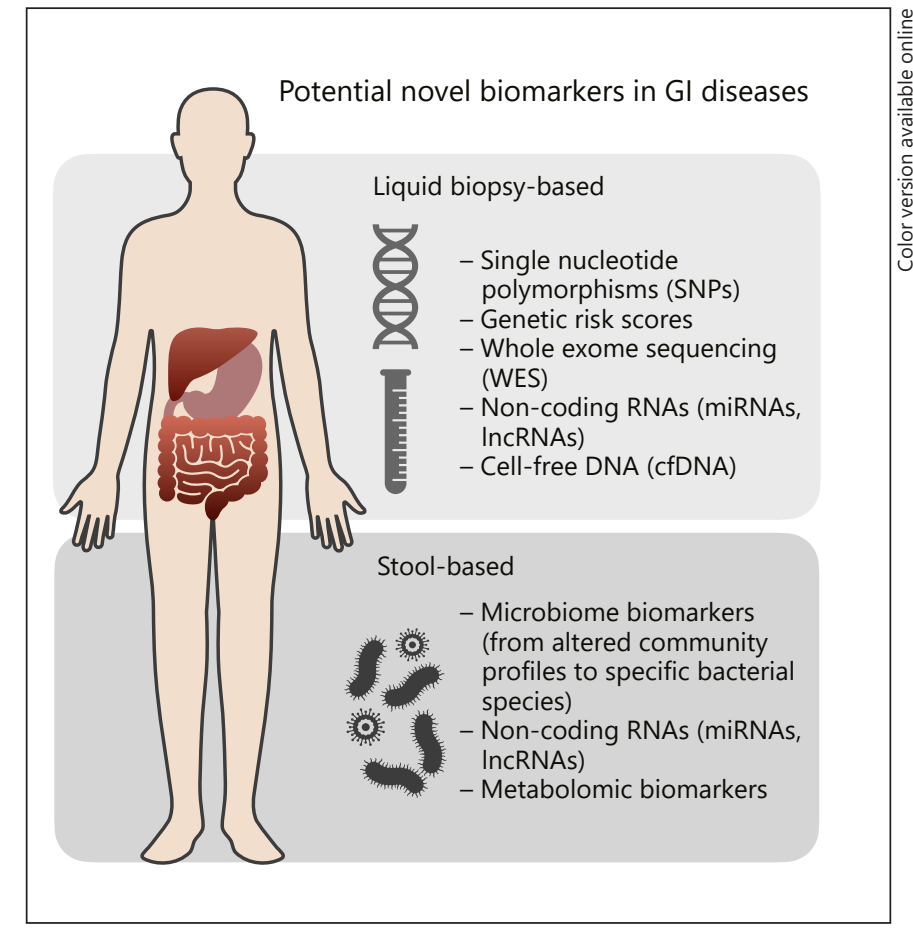

Fig. 1. Promising novel groups of biomarkers in gastrointestinal diseases.

cinskas et al. [29] found out that polymorphisms of PSCA gene (rs2976392 allele A; rs2294008 allele T) were associated with higher risk of GC and high-risk atrophic gastritis, while genetic variation of MUC1 (rs4072037 allele G) gene was protective. Another study discovered that rs 1051690 SNP in the INSR gene was associated with increased risk of GC, while polymorphisms in IL12B, CCND1, and IL10 genes were not linked with the presence of the disease [30]. A study by Dargiene et al. [31] concluded that TLR1 rs4833095 SNP was associated with an increased risk of GC, while genetic variant rs13361707 of PRKAA1 gene had no connection with GC.

Another large group of diseases that genetic studies focus on is liver disease. A study released in the year 2017 focused on 4 genes; it was concluded that SNPs in PNPLA3 and RNF7 genes were associated with higher risk of developing liver fibrosis or liver cirrhosis (LC), while MERTK and PCSK7 SNPs had no connection with both conditions [32]. A meta-analysis by Wang et al. [33] came to a conclusion that SNP rs2596542G $>$ A in the MICA gene is associated with $\mathrm{HCV}$-induced hepatocellular carcinoma (HCC) susceptibility in Asian, Caucasian, and African populations. Even though some studies showed that TM6SF2 rs58542926 and MBOAT7 rs641738 might be risk factors for alcoholic LC and nonalcoholic fatty liver disease, a study by Basyte- 
Table 1. Summary of investigated novel biomarkers in GI diseases

\begin{tabular}{|c|c|c|}
\hline Biomarker & Key findings and possible uses & Limitations \\
\hline $\begin{array}{l}\text { SNP GRSs } \\
\text { WES }\end{array}$ & $\begin{array}{l}\text { GWASs were focused on associations between multiple SNPs } \\
\text { and various GI diseases } \\
\text { Multiple genetic loci have been associated with different GI } \\
\text { diseases } \\
\text { GRSs are being developed in order to define individual } \\
\text { genetic susceptibility to various diseases } \\
\text { Novel WES studies that cover a much larger range of human } \\
\text { genome are underway and may provide more powerful } \\
\text { genetic disease prediction strategies }\end{array}$ & $\begin{array}{l}\text { Most associations between certain genetic variations and GI } \\
\text { diseases have an OR in the range of } 1.2-2.0 \rightarrow \text { limited potential to be } \\
\text { used for screening/diagnostic purposes and identify individuals at } \\
\text { risk } \\
\text { Different studies have reported results that sometimes are } \\
\text { contradictory } \\
\text { Unclear cost/benefit ratio }\end{array}$ \\
\hline ncRNAs & $\begin{array}{l}\text { ncRNAs show a lot of potential as noninvasive biomarkers for } \\
\text { both malignant and autoimmune GI disorders } \\
\text { ncRNAs might may narrow the gap in development of } \\
\text { noninvasive biomarkers for the diagnosis of IBD, GC, CRC, } \\
\text { and other conditions }\end{array}$ & $\begin{array}{l}\text { Numerous studies on the same ncRNAs have found controversial } \\
\text { results } \\
\text { Lack of consistent methodology } \rightarrow \text { bias created } \\
\text { A lot of studies report AUC of around } 0.8 \rightarrow \text { limited potential to be } \\
\text { used for screening/diagnostic purposes and identify individuals at } \\
\text { risk } \\
\text { Lack of prospective cohort and validation studies }\end{array}$ \\
\hline $\begin{array}{l}\text { Microbiome-based } \\
\text { biomarkers }\end{array}$ & $\begin{array}{l}\text { Deregulated microbiome profiles have been linked with } \\
\text { numerous GI diseases } \\
\text { Studies show that decreased diversity, lower levels of certain } \\
\text { microbiome species, increased microbiome instability, and } \\
\text { reduced anti-inflammatory taxa are found in IBD patients } \\
\text { Fecal and mucosal microbiome markers were shown to be } \\
\text { efficient predictors of treatment response, disease relapse, } \\
\text { progression, or postoperative recurrence } \\
\text { Several microbiome species have been linked with different } \\
\text { GI cancers, such as increased risk of CRC }\end{array}$ & $\begin{array}{l}\text { Studies have shown microbiome alterations related to different } \\
\text { diseases; however, the results of the studies are partly inconsistent } \\
\text { Lack of standardization in the process of specimen collection, } \\
\text { preparation and analysis for interpretation, and reproducibility of } \\
\text { the results } \\
\text { Very limited data that would currently provide real clinical benefit } \\
\text { and impact decisions in daily clinical practice }\end{array}$ \\
\hline
\end{tabular}

SNPs, single-nucleotide polymorphisms; GWASs, genome-wide association studies; WES, whole-exome sequencing; GI, gastrointestinal; OR, odds ratio; ncRNAs, noncoding RNAs; IBD, inflammatory bowel disease; GC, gastric cancer; CRC, colorectal cancer; AUC, area under the curve; cfDNA, cell-free DNA; ctDNA, circulating tumor DNA; GRS, genetic risk score.

Bacevice et al. [34] in the year 2019 concluded that these genetic variations were not linked to the mentioned conditions in eastern European population. Another research by the same authors revealed that SERPINA1 (Pi*S rs17580 variant) conferred an increased risk of developing liver fibrosis, while SERPINA1 ( $\mathrm{Pi}^{*} \mathrm{Z}$ rs28929474 variant) and HSD 17B13 rs10433937 were not associated with the disease [35]. A few studies have shown associations between SNP rs738409 of PNPLA3 gene and nonalcoholic fatty liver disease [36-38].

Some studies focus on associations between genetic variations and survival of cancer patients. A study by Rizzato et al. [39] analyzed effects of various SNPs on OS of pancreatic ductal adenocarcinoma patients; the research concluded that 3 SNPs (2p12-rs1567532, 10q26rs10764826, and 2p11-rs13431245) had statistically significantly worse and 2 SNPs (9p33-rs10818020 and 6p21rs12209785) had a longer OS. Pancreatic cancer risk was investigated by Campa et al. [40] in the year 2016; the study found a strong association between the A allele of rs3217992 SNP (CDKN2B gene) and increased risk of pancreatic ductal adenocarcinoma in Caucasian populations. Another research found 3 novel pancreatic cancer susceptibility signals marked by SNPs rs 2816938 at chromosome 1q32.1 (NR5A2), rs10094872 at 8q24.21 (MYC), and rs35226131 at 5p15.33 (CLPTM1L-TERT) [41]. 
In recent years, genetic variations in various intestinal diseases have also been a subject of interest by multiple studies. An investigation in the year 2014 found no associations between gene polymorphisms of multiple miRNAs and the presence of colorectal cancer (CRC) in European patients [42]. Barontini et al. [43] did not discover any statistically significant association between risk of developing CRC and selected 6 SNPs (rs860170, rs978739, rs1357949, rs1525489, rs6466849, and rs10268496) in TAS2R16 gene. Interestingly, one study found out that a variant of COL3A1 (rs3134646) was associated with an increased risk of developing colonic diverticulosis in white men, while SNPs rs1800255 (COL3A1) and rs1800012 (COL1A1) were not associated with the disease [44]. Some GWAS have identified SNP rs17810546 in a noncoding region on chromosome 3 as a risk factor for celiac disease [45]. A wide systematic review and meta-analysis by Zhu et al. [46] concluded that SNPs rs4263839 and rs6478108 of TNFSF15 gene were associated with an increased risk of irritable bowel syndrome (IBS), while rs1800896 GG genotype (IL10 gene) was linked to a decreased risk of IBS. SNPs might even be useful in prediction of inflammatory bowel disease (IBD) progression [47]. Recent analysis revealed that in Japanese populations, the IL23R rs76418789 was a susceptibility locus for ulcerative colitis (UC) and had a genomewide significant association [48]. Some GWASs have identified novel biomarkers significantly associated with CRC risk in Japanese (IRF8-FOXF1 rs847208 and TOX2 rs6065668) [49] and African-American populations (SYMPK rs56848936) [50]. Some centers used polymorphisms of thiopurine methyltransferase and inosine triphosphate pyrophosphatase for predicting the side effects of thiopurines (azathioprine) in management of IBD [51], but the decreasing use of this group of medications, especially among IBD patients, does not make this approach significantly useful in everyday GI clinical practice.

The new approach that has been more recently used to estimate an individual's genetic liability to various diseases is the genetic risk score (GRS), which takes into account multiple SNPs $[52,53]$. This is quite a new approach, and there is still a lack of studies in regard to GI diseases. A study by Zupančič et al. [54] combined 33 SNPs and found out that Slovenian individuals with the highest risk (GRS > 5.54) showed significantly increased odds of developing Crohn's disease compared to the study subjects with the lowest risk (GRS < 4.57). Another study by Xin et al. [55] concluded that a simple count GRS model might be optimal for predicting the genetic risk of
CRC. A German CRC screening study derived a GRS based on 48 SNPs associated with the disease and concluded that increased GRS was associated with an increased prevalence of advanced neoplasms [56].

One of the major problems associated with clinical use of SNPs is linked to the fact that most of the significant associations between certain genetic variations and GI diseases have an odds ratio in the range of 1.2-2.0; thus, their ability to be used for screening purposes and identify individuals at risk of certain conditions remains very limited $[57,58]$. More advanced research of genetic variations is expected to come from the novel whole-exome sequencing (WES) studies, which are even more focused on personalized medicine and should cover a much larger range of human genome as compared to the GWAS approach. Some scientists have already used WES in order to examine CRC [59-61] or liver diseases [62, 63].

\section{miRNAs and Noncoding RNAs}

Over the last few decades, a great deal of effort has been put into researching ncRNAs as biomarkers for various disorders from autoimmune diseases to cancer. Examples of these RNAs include miRNAs, long ncRNAs, circular RNAs, small nuclear RNAs, ribosomal RNAs, and transfer RNAs. ncRNAs are not translated into proteins but play an important role in a variety of physiological functions [64, 65].

There is a distinct lack of accurate noninvasive markers for the diagnosis of IBD, and ncRNAs were identified as candidates to fill this gap. In 2008, deregulated miRNAs have been identified in the colonic tissues of patients with UC [66]. Since then, there have been several reports stating correlation of ncRNA expression between colonic tissues and peripheral blood or feces $[67,68]$, and ncRNA expression is continuously investigated in feces or peripheral blood and its components. Several studies have reported distinct ncRNA expression in feces of IBD patients and healthy controls [69-72], and many studies have reported altered ncRNA expression in the peripheral blood of IBD patients [67, 68, 71, 73-92], although there are differences in the amount of deregulated ncRNAs and their diagnostic accuracy being reported. While some studies show unremarkable accuracy of ncRNAs in distinguishing between patients and healthy controls with receiver operating characteristics analysis showing an area under the curve (AUC) of $0.65-0.79$ [ 80 , $84,86]$, others report really promising results with an AUC of 0.97-0.99 for miRNA pairs of miR-215/miR-30e-
Jonaitis/Kiudelis/Streleckiene/Gedgaudas/ Skieceviciene/Kupcinskas 
3p, miR-215/miR-145, and miR-203/miR-145 [81]; 0.94 for serum miR-372 [67]; 0.88 for fecal miR-223 [71]; and 0.91 for miR-874-3p in distinguishing between colonic Crohn's disease and UC. However, when comparing different studies, the results are varied and sometimes inconsistent. This may be due to different methodologies employed by researchers; the methods of RNA extraction, normalization, sequencing, and even the source (whole blood, plasma, serum, or cells like mononuclear cells or platelets) may create bias, and this makes comparing data difficult.

Despite declining incidence [93], GC still provides great challenges for clinicians. Therefore, a lot of effort is being put into finding novel noninvasive biomarkers to aid in the early diagnosis of this disease, with ncRNAs being prime candidates for this role. An overwhelming amount of studies have been published during the last decade, and some of them report very promising results in distinguishing GC patients from controls, with an AUC 0.96 for plasma miR-940 [94], 0.94 for plasma miR139 [95], 0.90 for serum miR-16 [96], 0.912 for serum miR-21 [97], and 0.96 for plasma miR-451 [98]. However, most ncRNAs show lower AUC values of 0.6-0.8 [96, 99111]. The studies also display significant methodological differences and sometimes report conflicting results, where one miRNA is upregulated in one study and downregulated in another [112-114].

Esophageal cancer is one of the most common oncologic disorders in the world, and its 5-year survival rate is generally poor [115]. Like in many other conditions, ncRNAs are being investigated to fill the gap of noninvasive biomarkers for the early diagnosis of this condition [116-125]. Several studies show good diagnostic accuracy with an AUC of 0.95-0.96 for serum miR-18a [125], 0.9 for serum miR-31 [120], and 0.95 for serum miR-22 [119]. That being said, most studies showed less impressive results, with an AUC around 0.8, and once again, the same problem of heterogeneous reports is present.

CRC is the third most common malignant disorder in the world, and despite screening programs, the morality rate remains high [126]. Therefore, ncRNAs are being investigated as possible noninvasive biomarkers to facilitate early diagnosis of this pathology, and the AUC for distinguishing various stages of CRC from controls usually varies between 0.7 and 0.8 , up to 0.95 [127-134]. Furthermore, several meta-analysis reports have indicated that several ncRNA panels might be more accurate for cancer diagnosis than single ncRNAs [135-137].

In conclusion, a great number of proof-of-principle studies have been published, showing that ncRNAs show a lot of potential as noninvasive biomarkers for both malignant and autoimmune GI disorders, but we are still a long way from clinical practice. While some reports state excellent diagnostic accuracy, the heterogeneity of results in different studies leaves us with doubts and suggests that improvement and standardization of research protocols, as previously stated [138], are necessary. Furthermore, all these results still need to be confirmed in prospective cohort studies.

\section{Exome Sequencing and cfDNA: Focus on Cancer}

Blood-based testing and the potential of liquid biopsies have led to much research into noninvasive blood biomarkers. Circulating cell-free DNA (cfDNA) has emerged as a novel potential molecular analyte for various conditions including cancer, while the molecular profile of tumor material is typically assessed by invasive techniques such as biopsies. Circulating tumor DNA (ctDNA) shed by primary tumors or metastatic tumor sites and harboring genetic alterations of tissues of origin could serve as a powerful tool for the disease state, relapse, and response to therapy monitoring $[139,140]$.

Investigation of cfDNA first implements analysis of total cfDNA yield and integrity. It was observed in numerous studies that the yield of total cfDNA is dramatically increased in plasma of patients with GI cancers [141-147]. It was also showed that cfDNA could be more sensitive than classical oncoproteins in early screening of GC [143] and may be associated with various clinical features such as tumor relapse [144], progression-free, and OS time [142].

Moreover, a minor fraction of cfDNA-ctDNA could carry more relevant information. High-throughput and sensitive techniques such as new-generation sequencing or digital droplet PCR led to numerous studies, analyzing tumor tissue-derived alterations. Majority of studies analyzed alterations of single genes, associated with cancerous processes. TP53 gene alterations are still considered responsible for around half of esophageal and GC cases [148, 149], and analysis of tumors harboring TP53 mutations revealed that ctDNA could be used for monitoring of esophageal [150-152] and gastric [153] tumor status. Studies also showed that ctDNA could serve as an effective tool for evaluating treatment effectiveness, while KRAS mutations associated with acquired resistance were detected in esophageal cancer patients' blood [154]. Tumor reoccurrence or minimal residual disease risk was also successfully assessed by analyzing variant allele frequencies of mutated genes 
such as TP53, ERBB2, FAT3, and HER2 [151, 155-158] in case of esophageal, GC, and HCC. In addition to single gene mutational analysis, MYC2 and HER2 gene amplification analysis could be applied as a screening target for GC $[159,160]$. On the other hand, the most investigated ctDNA marker in CRC and pancreatic cancers is KRAS gene, and studies show promising results for applying this gene for the purposes of prognosis, detection of metastases, and determination of response to immunotherapy [161-164]. Other genes that have been investigated through ctDNA in the case of CRC are APC, BRAF, and TP53. All 3 of these genes have shown a high specificity for CRC detection similar to that of KRAS $[164,165]$. Although studies report low amounts of cfDNA in pancreatic cancer cases [166, 167], in the study conducted by Sausen et al. [166], it was observed that using mutations in cfDNA, pancreatic cancer recurrences could be detected approximately 6 months before the detection by imaging tests.

Gene panels, WES, or whole-genome sequencing allows to evaluate wide mutational profile, concordance of mutational profiles between cfDNA and tissue, and novel potential targets. Taking into consideration the heterogeneous nature of GI tumors, especially GC and HCC, the concordance rate varies greatly and usually does not reach $50 \%[156,168-170]$. Interestingly, in the case of $\mathrm{CRC}$, the concordance rate of mutations in plasma with corresponding tumor tissue was generally high with over $85 \%$ [171-173]. A low concordance rate could be explained by tumoral heterogeneity as the plasma cfDNA mutational profile is usually compared with a single-site biopsy sample. In that case, plasma cfDNA or liquid biopsies could reflect an even more accurate genetic profile and have advantage over single-site biopsy.

The application of ctDNA analysis as a noninvasive biomarker in GI malignancies is promising, while the research reveals that it could be related to a tumor state, prognosis, and disease recurrence rate. Although ctDNA analysis is highly diverse and could include various approaches (from estimation of the total cfDNA yield to whole-genome sequencing), evaluation of cancer-related alterations during the course of a disease in a noninvasive manner would undoubtedly improve diagnostics, prognostics, and even treatment of GI cancer patients.

\section{Microbiome-Based Biomarkers: Diagnostic Potential}

The human microbiota is extremely diverse and complex. Unique profiles of microbiome have been identified in nearly all human body parts. Bacteria, viruses, archaea, fungi, and protozoa inhabit surfaces of the skin and urogenital system; however, the richest microbiome is found in the GI tract: the large intestine accounts for around $70 \%$ of all the human bacteria. Microbiome is a crucial part for a healthy state of an individual as it plays an important role in fermentation, metabolism, and immunity training [174].

Disruption of microbiome homeostasis has been linked with numerous diseases. A classic example of dysbiosis-related disease is Clostridium difficile colitis, which, even if treated successfully, has significant reoccurrence rates due to persistent dysbiosis. Therefore, the re-establishment of the microbiome equilibrium via fecal microbiota transplantation shows tremendous success in treatment of this disease [175].

Gut microbiome is thought to be one of the key players in IBD pathogenesis as most of genetic mutations in these patients have been linked to interactions of the immune system and microbiome [176]. Decreased diversity, lower levels of Firmicutes, higher levels of Proteobacteria, increased microbiome instability, and reduced anti-inflammatory taxa are common findings in microbiome studies of IBD patients [177]. There are studies that identified bacterial families like Enterobacteriaceae, Veillonellaceae, and Fusobacteriaceae to be enriched and members of Bacteroidales and Clostridiales to be depleted in patients as compared to controls. Faecalibacterium prausnitzii has been suggested as a potentially protective and beneficial species [178-181]. Fecal and mucosal microbiome markers were shown to be efficient predictors of treatment response, disease relapse, progression or postoperative recurrence, and a promising diagnostic biomarker with an accuracy of $>80 \%[179,182-189]$.

Microbiome studies have been of interest in IBS cases as well. Series of studies described fecal microbiome alterations related to IBS; however, results are inconsistent [190-192]. A recent population study of IBS microbiome showed no proof for altered microbiome in either stool or mucosa [193].

It is assumed that up to $20 \%$ of cancers might be related to infectious agents [194]. Probably, the best-known pathogen related to cancer is Helicobacter pylori, which is associated with $>90 \%$ of GCs. For its inflammatory, direct genotoxic effect, as well as effect and capacity of transforming benign lesions to premalignant and malignant state, it has been classified as a class I carcinogen by the World Health Organization [195].

Recent publications revealed that gastric carcinogenesis is associated with dysbiosis. Oral bacteria and other microbes like Prevotella intermedia, Prevotella oris, and
Jonaitis/Kiudelis/Streleckiene/Gedgaudas/ Skieceviciene/Kupcinskas 
Fusobacterium nucleatum might also play a role in development and progression of this malignancy [196]. The incidence of colon cancer can be related to genetic alterations in only a fraction of patients. Uninterrupted contact with colonizing bugs in the colon led to hypothesis that microbiome might be involved. Studies show that CRC could be associated with species such as Streptococcus bovis, Helicobacter pylori, Clostridium septicum, Bacteroides fragilis, adherent Escherichia coli, Enterococcus faecalis, and its toxins [197, 198]. Recently, more attention has been paid to Fusobacterium nucleatum, which has been found in tumor tissue, metastatic lymph nodes, and even liver metastasis. It is thought to play a role in development and progression of CRC by causing alterations in signaling pathways related to carcinogenesis $[199,200]$. Intratumoral load of these bacteria in cancer tissue is related to poor prognosis [201]. F. nucleatum alone or in combination with other bacteria has been proposed as noninvasive diagnostic biomarkers with even higher accuracy than the fecal immunochemical test [202-206].

Recently, progresses have been made in determining the structure of previously stated sterile compartments. Studies have showed that patients with LC, acute or chronic hepatitis $\mathrm{B}$, and alcoholic hepatitis have altered microbiome composition [207-209]. Moreover, using a blood-derived microbiome signature showed diagnostic accuracy of around $80 \%$ when identifying patients with HCC [210]. Even more fascinating diagnostic capabilities of circulating microbiome were investigated by Poore et al. [211]. Using machine-learning trained classifier, authors correlated blood microbial signatures with cancer detection and were able to detect cancer patients at stages as early as Ia or IIc and be cancer type-specific.

Microbiome analysis in various body parts and fluids shows great potential as a novel noninvasive biomarker for diagnostics and monitoring of various diseases. However, substantial effort is needed to standardize the process of specimen collection, preparation and analysis for interpretation, and reproducibility of the results.

\section{Future Prospects of Biomarkers}

Most of the currently researched potential biomarkers have not yet been validated and approved to be used in real-life clinical practice for screening purposes or diagnostics of specific GI diseases; however, the future of biomarkers looks promising. Even though some studies show excellent diagnostic accuracy of various biomarkers, the heterogeneity of the results leaves us with doubts.
Therefore, further large-scale studies and clinical trials with standardized methods designed by multicenter consortiums are needed. As already mentioned in the article, most modern diagnostic approaches, such as WES studies, should cover a much larger range of human genome. One of the currently researched and most promising diagnostic methods is single cell sequencing, which measures gene expression at the single-cell level and has the advantage of detecting heterogeneity among individual cell groups or even individual cells [212-215]. Constant development of novel molecular diagnostic approaches and validation of currently researched biomarkers should lead to a faster and more accurate data processing as well as the cost reduction of these diagnostic methods, which would result in increased availability and better implementation in real-life clinical setting. As of today, diagnostic biomarkers seem to be a significant part of personalized medicine, which could become one of the main therapeutic approaches in the near future.

\section{Conclusion}

The recent progress in modern diagnostic methods leads to a conclusion that personalized medicine might become the main diagnostic and therapeutic approach in the near future for different GI diseases. Various novel biomarkers, such as genetic variations, miRNAs, cfDNA, or microbiome-based biomarkers, are currently among the main translational research targets. Some of these biomarkers have strong associations with various disorders and have the potential to be used as one of the tools in the diagnostics, prognosis, and treatment of different GI diseases. However, the use of these biomarkers in real-life clinical practice is still very limited as most of investigated molecular biomarkers still lack required specificity and sensitivity for real life clinical applications. Further largescale studies are needed to elucidate the ultimate role of the abovementioned potential noninvasive biomarkers in management of benign and malignant GI diseases.

\section{Statement of Ethics}

No ethical approval is required.

\section{Conflict of Interest Statement}

The authors have no conflicts of interest to declare. 


\section{Funding Sources}

The authors did not receive any funding.

\section{Author Contributions}

J.K. and J.S. were the supervisors of the manuscript and reviewed and finalized the final version of the manuscript. P.J. prepared and designed the first draft of the manuscript and contributed to the part about SNPs. V.K. contributed to the part about miRNAs and ncRNAs. G.S. contributed to the part about exome sequencing and cfDNA and created the illustration of the manuscript. R.G. contributed to the part about microbiome-based biomarkers. All authors approved for the final manuscript.

\section{References}

1 Hsueh CT, Liu D, Wang H. Novel biomarkers for diagnosis, prognosis, targeted therapy and clinical trials. Biomark Res. 2013;1(1): $1-2$.

2 Mayeux R. Biomarkers: potential uses and limitations. NeuroRx. 2004;1(2):182-8.

3 Giampaoli S, Palmieri L, Mattiello A, Panico S. Definition of high risk individuals to optimise strategies for primary prevention of cardiovascular diseases. Nutr Metab Cardiovasc Dis. 2005 Feb;15(1):79-85.

4 Singhi AD, Koay EJ, Chari ST, Maitra A. Early detection of pancreatic cancer: opportunities and challenges. Gastroenterology. 2019 May;156(7):2024-40.

5 Hayes J, Peruzzi PP, Lawler S. MicroRNAs in cancer: biomarkers, functions and therapy. Trends Mol Med. 2014;20(8):460-9.

6 Novelli G, Ciccacci C, Borgiani P, Papaluca Amati M, Abadie E. Genetic tests and genomic biomarkers: regulation, qualification and validation. Clin Cases Miner Bone Metab. 2008;5(2):149-54.

7 Yang YB. The role of genetics in medicine: a future of precision medicine. B C Med J. 2019; 61(10):388-9.

8 Di Sanzo M, Cipolloni L, Borro M, La Russa R, Santurro A, Scopetti M, et al. Clinical applications of personalized medicine: a new paradigm and challenge. Curr Pharm Biotechnol. 2017;18(3):194-203.

9 Dorcely B, Katz K, Jagannathan R, Chiang SS, Oluwadare B, Goldberg IJ, et al. Novel biomarkers for prediabetes, diabetes, and associated complications. Diabetes Metab Syndr Obes. 2017;10:345-61.

10 Garcia-Contreras M, Brooks RW, Boccuzzi L, Robbins PD, Ricordi C. Exosomes as biomarkers and therapeutic tools for type 1 diabetes mellitus. Eur Rev Med Pharmacol Sci. 2017;21(12):2940-56.

11 Jin Y, She JX. Novel biomarkers in type 1 diabetes. Rev Diabet Stud. 2012;9(4):224-35.

12 Odle TG. Precision medicine in breast cancer. Radiol Technol. 2017 Mar;88(4):401M-21M.

13 Jia Y, Chen Y, Wang Q, Jayasinghe U, Luo X. Exosome: emerging biomarker in breast cancer. Oncotarget. 2017;8(25):41717-33.

14 Nassar FJ, Nasr R, Talhouk R. MicroRNAs as biomarkers for early breast cancer diagnosis, prognosis and therapy prediction. Pharmacol Ther. 2017;172:34-49.
15 Basavaraju M, de Lencastre A. Alzheimer's disease: presence and role of microRNAs. Biomol Concepts. 2016 Aug;7(4):241-52.

16 Reitz C. Genetic diagnosis and prognosis of Alzheimer's disease: challenges and opportunities. Expert Rev Mol Diagn. 2015 Mar;15(3): $339-48$.

17 Köberle B, Koch B, Fischer BM, Hartwig A. Single nucleotide polymorphisms in DNA repair genes and putative cancer risk. Arch Toxicol. 2016;90(10):2369-88.

18 Shen LX, Basilion JP, Stanton VP. Single-nucleotide polymorphisms can cause different structural folds of mRNA. Proc Natl Acad Sci U S A. 1999;96(14):7871-6.

19 Nelson MR, Marnellos G, Kammerer S, Hoyal CR, Shi MM, Cantor CR, et al. Large-scale validation of single nucleotide polymorphisms in gene regions. Genome Res. 2004; 14(8):1664-8.

20 Matsuda K. PCR-based detection methods for single-nucleotide polymorphism or mutation: real-time PCR and its substantial contribution toward technological refinement. Adv Clin Chem. 2017;80:45-72.

21 Nogales A, Dediego ML. Host single nucleotide polymorphisms modulating influenza a virus disease in humans. Pathogens. 2019; $8(4): 1-22$.

22 Deng N, Zhou H, Fan H, Yuan Y. Single nucleotide polymorphisms and cancer susceptibility. Oncotarget. 2016;8(66):231-9.

23 Fagny M, Platig J, Kuijjer ML, Lin X, Quackenbush J. Nongenic cancer-risk SNPs affect oncogenes, tumour-suppressor genes, and immune function. Br J Cancer. 2020;122(4): 569-77.

24 Hazelett DJ, Conti DV, Han Y, Al Olama AA, Easton D, Eeles RA, et al. Reducing GWAS complexity. Cell Cycle. 2016;15(1):22-4.

25 Marees AT, Kluiver H, Stringer S, Vorspan F, Curis E, Claire M, et al. A tutorial on conducting genome-wide association studies: quality control and statistical analysis. Int J Methods Psychiatr Res. 2018;27(1608):1-10.

26 Kupcinskas J, Wex T, Bornschein J, Selgrad M, Leja M, Juozaityte E, et al. Lack of association between gene polymorphisms of angiotensin converting enzyme, nod-like receptor 1, toll-like receptor 4, FAS/FASL and the presence of Helicobacter pylori-induced premalignant gastric lesions and gastric cancer in
Caucasians. BMC Med Genet. 2011;12(1): 112.

27 Kupcinskas L, Wex T, Kupcinskas J, Leja M, Ivanauskas A, Virgilijus L, et al. Interleukin$1 \mathrm{~B}$ and interleukin-1 receptor antagonist gene polymorphisms are not associated with premalignant gastric conditions: a combined haplotype analysis. Eur J Gastroenterol Hepatol. 2010;22:1189-95.

28 Kupcinskas J, Wex T, Link A, Leja M, Bruzaite I, Steponaitiene R, et al. Gene polymorphisms of micrornas in Helicobacter pylori-induced high risk atrophic gastritis and gastric cancer. PLoS One. 2014;9(1):e87467-8.

29 Kupcinskas J, Wex T, Link A, Bartuseviciute R, Dedelaite M, Kevalaite G, et al. PSCA and MUC1 gene polymorphisms are linked with gastric cancer and pre-malignant gastric conditions. Anticancer Res. 2014;34(14):7167-75.

30 Petkevicius V, Salteniene V, Juzenas S, Wex T, Link A, Leja M, et al. Polymorphisms of microRNA target genesIL12B,INSR,CCND1, and IL10 in gastric cancer. World J Gastroenterol. 2017;23(19):3480-7.

31 Dargiene G, Streleckiene G, Skieceviciene J, Leja M, Link A, Wex T, et al. TLR1 and PRKAA1 gene polymorphisms in the development of atrophic gastritis and gastric cancer. J Gastrointestin Liver Dis. 2018;27(4): 363-9.

32 Kupcinskas J, Valantiene I, Varkalaitė G, Steponaitiene R, Skieceviciene J, Sumskiene J, et al. PNPLA3 and RNF7 gene variants are associated with the risk of developing liver fibrosis and cirrhosis in an Eastern European population. J Gastrointestin Liver Dis. 2017; 26(1):37-43.

33 Wang H, Cao H, Xu Z, Wang D, Zeng Y. SNP rs $2596542 \mathrm{G}>\mathrm{A}$ in MICA is associated with risk of hepatocellular carcinoma: a meta-analysis. Biosci Rep. 2019;39(5):1-13.

34 Basyte-Bacevice V, Skieceviciene J, Valantiene I, Sumskiene J, Petrenkiene V, Kondrackiene J, et al. TM6SF2 and MBOAT7 gene variants in liver fibrosis and cirrhosis. Int $\mathrm{J}$ Mol Sci. 2019;20(6):1277.

35 Basyte-Bacevice V, Skieceviciene J, Valantiene I, Sumskiene J, Petrenkiene V, Kondrackiene J, et al. SERPINA1 and HSD17B13 gene variants in patients with liver fibrosis and cirrhosis. J Gastrointestin Liver Dis. 2019; 28(3):297-302. 
36 Yang H, Chen G, Song C, Li D, Chen G, Li X. A novel index including SNPs for the screening of nonalcoholic fatty liver disease among elder Chinese: a population-based study. Medicine. 2018;97(13):e0272.

37 Macaluso FS, Maida M, Petta S. Genetic background in nonalcoholic fatty liver disease: a comprehensive review. World J Gastroenterol. 2015;21(39):11088-111.

38 Meffert P, Repp K, Volzke H, Weiss FU, Homuth G, Kuhn J, et al. The PNPLA3 SNP rs738409: $\mathrm{G}$ allele is associated with increased liver disease-associated mortality but reduced overall mortality in a population-based cohort. J Hepatol. 2018;68:858-60.

39 Rizzato C, Campa D, Talar-Wojnarowska R Halloran C, Kupcinskas J, Butturini G, et al. Association of genetic polymorphisms with survival of pancreatic ductal adenocarcinoma patients. Carcinogenesis. 2016;37(10):95764.

40 Campa D, Pastore M, Gentiluomo M, TalarWojnarowska R, Kupcinskas J, Malecka-Panas E, et al. Functional single nucleotide polymorphisms within the cyclin-dependent kinase inhibitor $2 \mathrm{~A} / 2 \mathrm{~B}$ region affect pancreatic cancer risk. Oncotarget. 2016;7(35):5701120.

41 Zhang M, Wang Z, Obazee O, Jia J, Childs EJ Hoskins J, et al. Three new pancreatic cancer susceptibility signals identified on chromosomes 1q32.1, 5p15.33 and 8q24.21. Oncotarget. 2016;7(41):66328-43.

42 Kupcinskas J, Bruzaite I, Juzenas S, Gyvyte U, Jonaitis L, Kiudelis G, et al. Lack of association between miR-27a, miR-146a, miR196a-2, miR-492 and miR-608 gene polymorphisms and colorectal cancer. Sci Rep. 2014;4:5993-6.

43 Barontini J, Antinucci M, Tofanelli S, Cammalleri M, Dal Monte M, Gemignani F, et al. Association between polymorphisms of TAS2R16 and susceptibility to colorectal cancer. BMC Gastroenterol. 2017;17(1):104-7.

44 Reichert MC, Kupcinskas J, Krawczyk M, Jüngst C, Casper M, Grünhage F, et al. A variant of COL3A1 (rs3134646) is associated with risk of developing diverticulosis in white men. Dis Colon Rectum. 2018;61(5):604-11.

45 Zwiers A, Van Wanrooij RLJ, Dieckman T, Nijeboer P, Kraal G, Bouma G. Celiac disease associated SNP rs17810546 is located in a gene silencing region. Gene. 2020;726(June 2019): 144165

46 Zhu S, Wang B, Jia Q, Duan L. Candidate single nucleotide polymorphisms of irritable bowel syndrome: a systemic review and metaanalysis. BMC Gastroenterol. 2019;19(165) $1-10$.

47 Corson M, Jamaluddin N, Sauk J, Jacobs J, Rankin C, Padua D. SNP analysis as a potential predictor of disease progression within the UCLA IBD biobank. J Am Coll Gastroenterol. 2018;113:S400.

48 Okamoto D, Kakuta Y, Takeo N, Moroi R, Kuroha M, Kanazawa Y, et al. P822 genetic analysis of ulcerative colitis in Japanese indi- viduals using population-specific SNP array. J Crohns Colitis. 2020 Jan 15;14(Suppl_1): S638-9.

49 Tanikawa C, Kamatani Y, Takahashi A, Momozawa $Y$, Leveque $K$, Nagayama $S$, et al. GWAS identifies two novel colorectal cancer loci at 16q24.1 and 20q13.12. Carcinogenesis. 2018 May 3;39(5):652-60.

50 Wang H, Schmit SL, Haiman CA, Keku TO, Kato I, Palmer JR, et al. Novel colon cancer susceptibility variants identified from a genome-wide association study in African Americans. Int J Cancer. 2017;140(12):272833.

51 Steponaitiene R, Kupcinskas J, Survilaite S, Varkalaite G, Jonaitis L, Kiudelis G, et al. TPMT and ITPA genetic variants in Lithuanian inflammatory bowel disease patients: prevalence and azathioprine-related side effects. Adv Med Sci. 2016;61(1):135-40.

52 Niu DY, Yan WL. [The application of genetic risk score in genetic studies of complex human diseases]. Yi Chuan. 2015 Dec;37(12): 1204-10.

53 Cooke Bailey JN, Igo RP. Genetic risk scores. Curr Protoc Hum Genet. 2016 Oct;91:1-9.

54 Zupančič K, Skok K, Repnik K, Weersma RK, Potočnik U, Skok P. Multi-locus genetic risk score predicts risk for Crohn's disease in Slovenian population. World J Gastroenterol. 2016;22(14):3777-84.

55 Xin I, Chu H, Ben S, Ge Y, Shao W, Zhao Y, et al. Evaluating the effect of multiple genetic risk score models on colorectal cancer risk prediction. Gene. 2018;673(February):17480.

56 Weigl K, Thomsen H, Balavarca Y, Hellwege JN, Shrubsole MJ, Brenner H. Genetic risk score is associated with prevalence of advanced neoplasms in a colorectal cancer screening population. Gastroenterology. 2018;155(1):88-98.

57 Jonaitis P, Jonaitis L, Kupcinskas J. Role of genetic polymorphisms of cytochrome P450 2C19 in pantoprazole metabolism and pantoprazole-based Helicobacter pylori eradication regimens. Curr Drug Metab. 2020 May; 21(11):830-7.

58 Bornschein J, Leja M, Kupcinskas J, Link A, Weaver J, Rugge M, et al. Molecular diagnostics in gastric cancer. Front Biosci. 2014;19: 312-38.

59 Yan P, Wang Y, Meng X, Yang H, Liu Z, Qian $\mathrm{J}$, et al. Whole exome sequencing of ulcerative colitis-associated colorectal cancer based on novel somatic mutations identified in Chinese patients. Inflamm Bowel Dis. 2019;25(8): 1293-301.

60 Roberts JN, Zhang M, Traverso G, Robles IA, Khan AM, Joseph C, et al. Whole-exome sequencing analyses of inflammatory bowel disease-associated colorectal cancers. Gastroenterology. 2017;150(4):931-43.

61 Toma C, Díaz-Gay M, Franch-Expósito S, Arnau-Collell C, Overs B, Muñoz J, et al. Using linkage studies combined with whole-exome sequencing to identify novel candidate genes for familial colorectal cancer. Int J Cancer. 2020;1577(146):1568-77.

62 Rakela J, Rule J, Ganger D, Lau J, Cunningham J, Dehankar M, et al. Whole exome sequencing among 26 patients with indeterminate acute liver failure: a Pilot Study. Clin Transl Gastroenterol. 2019;10:1-5.

63 Bale G, Vishnubhotla RV, Mitnala S, Sharma M, Padaki RN, Pawar SC, et al. Wholeexome sequencing identifies a variant in phosphatidylethanolamine N-methyltransferase gene to be associated with lean-nonalcoholic fatty liver disease. J Clin Exp Hepatol. 2019 Sep-Oct;9(5):561-8.

64 Moran VA, Perera RJ, Khalil AM. Emerging functional and mechanistic paradigms of mammalian long non-coding RNAs. Nucleic Acids Res. 2012;40(14):6391-400.

65 Mehta A, Baltimore D. MicroRNAs as regulatory elements in immune system logic. Nat Rev Immunol. 2016 Apr;16(5):279-94.

66 Wu F, Zikusoka M, Trindade A, Dassopoulos T, Harris ML, Bayless TM, et al. MicroRNAs are differentially expressed in ulcerative colitis and alter expression of macrophage inflammatory peptide-2 alpha. Gastroenterology. 2008;135(5):1624-e24.

67 Shen M, Meng L. Peripheral blood miR-372 as a biomarker for ulcerative colitis via direct targeting of NLRP12. Exp Ther Med. 2019; 18(2):1486-92

68 Wang S, Hou Y, Chen W, Wang J, Xie W, Zhang X, et al. KIF9-AS1, LINC01272 and DIO3OS IncRNAs as novel biomarkers for inflammatory bowel disease. Mol Med Rep. 2018;17(2):2195-202.

69 Verdier J, Breunig IR, Ohse MC, Roubrocks S, Kleinfeld S, Roy S, et al. Faecal micro-RNAs in inflammatory bowel diseases. J Crohns Colitis. 2020;14(1):110-7.

70 Wohnhaas CT, Schmid R, Rolser M, Kaaru E, Langgartner D, Rieber K, et al. Fecal MicroRNAs show promise as noninvasive Crohn's disease biomarkers. Crohns Colitis 360. 2020; 2(1):otaa003-12.

71 Schönauen K, Le N, Von Arnim U, Schulz C, Malfertheiner P, Link A. Circulating and fecal microRNAs as biomarkers for inflammatory bowel diseases. Inflamm Bowel Dis. 2018; 24(7):1547-57.

72 Ji Y, Li X, Zhu Y, Li N, Zhang N, Niu M. Faecal microRNA as a biomarker of the activity and prognosis of inflammatory bowel diseases. Biochem Biophys Res Commun. 2018; 503(4):2443-50.

73 Mohammadnia-Afrouzi M, Hosseini AZ Khalili A, Abediankenari S, Amari A, Aghili $B$, et al. Altered microRNA expression and immunosuppressive cytokine production by regulatory t cells of ulcerative colitis patients. Immunol Invest. 2016;45(1):63-74.

74 Chen P, Li Y, Li L, Yu Q, Chao K, Zhou G, et al. Circulating microRNA146b-5p is superior to C-reactive protein as a novel biomarker for monitoring inflammatory bowel disease. Aliment Pharmacol Ther. 2019; 49(6):733-43. 
75 Omidbakhsh A, Saeedi M, Khoshnia M, Marjani A, Hakimi S. Micro-RNAs -106a and $-362-3 p$ in peripheral blood of inflammatory bowel disease patients. Open Biochem J. 2018; 12(1):78-86.

76 He C, Shi Y, Wu R, Sun M, Fang L, Wu W, et al. miR-301a promotes intestinal mucosal inflammation through induction of IL-17A and TNF- $\alpha$ in IBD. Gut. 2016;65(12):193850.

77 Mohammadi A, Kelly OB, Filice M, Kabakchiev B, Smith MI, Silverberg MS. Differential expression of microRNAs in peripheral blood mononuclear cells identifies autophagy and TGF-beta-related signatures aberrantly expressed in inflammatory bowel disease. J Crohns Colitis. 2018;12(5):568-81.

78 Paraskevi A, Theodoropoulos G, Papaconstantinou I, Mantzaris G, Nikiteas N, Gazouli M. Circulating MicroRNA in inflammatory bowel disease. J Crohns Colitis. 2012;6(9): 900-4.

79 Zahm AM, Thayu M, Hand NJ, Horner A, Leonard MB, Friedman JR. Circulating microRNA is a biomarker of pediatric crohn disease. J Pediatr Gastroenterol Nutr. 2011; 53(1):26-33.

80 Jensen MD, Andersen RF, Christensen $\mathrm{H}, \mathrm{Na}$ than T, Kjeldsen J, Madsen JS. Circulating microRNAs as biomarkers of adult Crohn's disease. Eur J Gastroenterol Hepatol. 2015;27(9): 1038-44.

81 Sheinerman KS, Tsivinsky VG, Umansky SR. Analysis of organ-enriched microRNAs in plasma as an approach to development of universal screening test: feasibility study. J Transl Med. 2013;11(304):304.

82 Netz U, Carter J, Eichenberger MR, Feagins K, Galbraith NJ, Dryden GW, et al. Plasma microRNA profile differentiates Crohn's colitis from ulcerative colitis. Inflamm Bowel Dis. 2018;24(1):159-65.

83 Sun CM, Wu J, Zhang H, Shi G, Chen ZT. Circulating miR-125a but not miR-125b is decreased in active disease status and negatively correlates with disease severity as well as inflammatory cytokines in patients with Crohn's disease. World J Gastroenterol. 2017; 23(44):7888-98.

84 Ye YL, Yin J, Hu T, Zhang LP, Wu LY, Pang Z. Increased circulating circular RNA_103516 is a novel biomarker for inflammatory bowel disease in adult patients. World J Gastroenterol. 2019;25(41):6273-88.

85 Krissansen GW, Yang Y, McQueen FM, Leung E, Peek D, Chan YC, et al. Overexpression of miR-595 and miR-1246 in the sera of patients with active forms of inflammatory bowel disease. Inflamm Bowel Dis. 2015; 21(3):520-30.

86 Polytarchou C, Oikonomopoulos A, Mahurkar S, Touroutoglou A, Koukos G, Hommes DW, et al. Assessment of circulating MicroRNAs for the diagnosis and disease activity evaluation in patients with ulcerative colitis by using the nanostring technology. Inflamm Bowel Dis. 2015;21(11):2533-9.
87 Wang H, Zhang S, Yu Q, Yang G, Guo J, Li $\mathrm{M}$, et al. Circulating MicroRNA223 is a new biomarker for inflammatory bowel disease. Medicine. 2016;95(5):e2703-6.

88 Oikonomopoulos A, Polytarchou C, Joshi S, Hommes DW, Iliopoulos D. Identification of circulating MicroRNA signatures in Crohn's disease using the nanostring nCounter technology. Inflamm Bowel Dis. 2016;22(9):2063-9.

89 Wu F, Guo NJ, Tian H, Marohn M, Gearhart S, Bayless TM, et al. Peripheral blood microRNAs distinguish active ulcerative colitis and Crohn's disease. Inflamm Bowel Dis. 2011;17(1):241-50.

90 Chen D, Liu J, Zhao HY, Chen YP, Xiang Z, Jin X. Plasma long noncoding RNA expression profile identified by microarray in patients with Crohn's disease. World J Gastroenterol. 2016;22(19):4716-31.

91 Schaefer JS, Attumi T, Opekun AR, Abraham B, Hou J, Shelby H, et al. MicroRNA signatures differentiate Crohn's disease from ulcerative colitis. BMC Immunol. 2015;16(1):5-13.

92 Duttagupta R, DiRienzo S, Jiang R, Bowers J, Gollub J, Kao J, et al. Genome-wide maps of circulating miRNA biomarkers for ulcerative colitis. PLoS One. 2012;7(2):e31241.

93 Lee YC, Chiang TH, Chou CK, Tu YK, Liao WC, Wu MS, et al. Association between $\mathrm{He}$ licobacter pylori eradication and gastric cancer incidence: a systematic review and metaanalysis. Gastroenterology. 2016;150(5): 1113-e5.

94 Liu X, Kwong A, Sihoe A, Chu KM. Plasma miR-940 may serve as a novel biomarker for gastric cancer. Tumour Biol. 2016;37(3): 3589-97.

95 Chen S, Zhu J, Yu F, Tian Y, Ma S, Liu X. Combination of miRNA and RNA functions as potential biomarkers for gastric cancer. Tumour Biol. 2015;36(12):9909-18.

96 Wang H, Wang L, Wu Z, Sun R, Jin H, Ma J, et al. Three dysregulated microRNAs in serum as novel biomarkers for gastric cancer screening. Med Oncol. 2014;31(12):298-7.

$97 \mathrm{Wu} \mathrm{J}$, Li G, Wang Z, Yao Y, Chen R, Pu X, et al. Circulating MicroRNA-21 is a potential diagnostic biomarker in gastric cancer. Dis Markers. 2015;2015:435656.

98 Konishi H, Ichikawa D, Komatsu S, Shiozaki A, Tsujiura M, Takeshita H, et al. Detection of gastric cancer-associated microRNAs on microRNA microarray comparing pre- and post-operative plasma. Br J Cancer. 2012; 106(4):740-7.

99 Zhou X, Zhu W, Li H, Wen W, Cheng W, Wang F, et al. Diagnostic value of a plasma microRNA signature in gastric cancer: a microRNA expression analysis. Sci Rep. 2015; 5(22): 11251

100 Zhou H, Guo JM, Lou YR, Zhang XJ, Zhong $\mathrm{FD}$, Jiang Z, et al. Detection of circulating tumor cells in peripheral blood from patients with gastric cancer using microRNA as a marker. J Mol Med. 2010;88(7):709-17.
101 Ayremlou N, Mozdarani H, Mowla SJ, Delavari $\mathrm{A}$. Increased levels of serum and tissue miR-107 in human gastric cancer: correlation with tumor hypoxia. Cancer Biomark. 2015;15(6):851-60.

102 Tsujiura M, Ichikawa D, Komatsu S, Shiozaki A, Takeshita H, Kosuga T, et al. Circulating microRNAs in plasma of patients with gastric cancers. Br J Cancer. 2010;102(7): 1174-9.

103 Liu S, Suo J, Wang C, Sun X, Wang D, He L, et al. Prognostic significance of low miR-144 expression in gastric cancer. Cancer Biomark. 2017 Dec;20(4):547-52.

104 Li C, Li JF, Cai Q, Qiu QQ, Yan M, Liu BY, et al. MiRNA-199a-3p: a potential circulating diagnostic biomarker for early gastric cancer. J Surg Oncol. 2013;108(2):89.

105 Oze I, Shimada S, Nagasaki H, Akiyama Y, Watanabe M, Yatabe Y, et al. Plasma microRNA-103, microRNA-107, and microRNA-194 levels are not biomarkers for human diffuse gastric cancer. J Cancer Res Clin Oncol. 2017;143(3):551-4.

106 Juzenas S, Salteniene V, Kupcinskas J, Link A, Kiudelis G, Jonaitis L, et al. Analysis of deregulated micrornas and their target genes in gastric cancer. PLoS One. 2015;10(7):1-20.

107 Cai H, Yuan Y, Hao YF, Guo TK, Wei X, Zhang YM. Plasma microRNAs serve as novel potential biomarkers for early detection of gastric cancer. Med Oncol. 2013; 30(1):452-6.

108 Wang N, Wang L, Yang Y, Gong L, Xiao B, Liu X. A serum exosomal microRNA panel as a potential biomarker test for gastric cancer. Biochem Biophys Res Commun. 2017; 493(3):1322-8.

109 Qiu X, Zhang J, Shi W, Liu S, Kang M, Chu H, et al. Circulating MicroRNA-26a in plasma and its potential diagnostic value in gastric cancer. PLoS One. 2016;11(3):e0151345-14.

110 Huang Z, Zhu D, Wu L, He M, Zhou X, Zhang L, et al. Six serum-based miRNAs as potential diagnostic biomarkers for gastric cancer. Cancer Epidemiol Biomarkers Prev. 2017;26(2):188-96.

111 Zhou H, Xiao B, Zhou F, Deng H, Zhang X, Lou Y, et al. MiR-421 is a functional marker of circulating tumor cells in gastric cancer patients. Biomarkers. 2012;17(2):104-10.

112 Zhu C, Ren C, Han J, Ding Y, Du J, Dai N, et al. A five-microRNA panel in plasma was identified as potential biomarker for early detection of gastric cancer. Br J Cancer. 2014;110(9):2291-9.

113 Treece AL, Duncan DL, Tang W, Elmore S, Morgan DR, Dominguez RL, et al. Gastric adenocarcinoma microRNA profiles in fixed tissue and in plasma reveal cancer-associated and Epstein-Barr virus-related expression patterns. Lab Invest. 2016;96(6):661-71.

114 Liu H, Zhu L, Liu B, Yang L, Meng X, Zhang $\mathrm{W}$, et al. Genome-wide microRNA profiles identify miR-378 as a serum biomarker for early detection of gastric cancer. Cancer Lett. 2012;316(2):196-203. 
115 Rustgi AK, El-Serag HB. Esophageal carcinoma. N Engl J Med. 2014;371(26):2499-509.

116 Tong YS, Wang XW, Zhou XL, Liu ZH, Yang TX, Shi WH, et al. Identification of the long non-coding RNA POU3F3 in plasma as a novel biomarker for diagnosis of esophageal squamous cell carcinoma. Mol Cancer. 2015;14(1):3-13.

117 Lin Y, Lin Z, Fang Z, Li H, Zhi X, Zhang Z. Plasma MicroRNA-34a as a potential biomarker for early diagnosis of esophageal cancer. Clin Lab. 2019 Nov;65(11).

118 Sun K, Zhao X, Wan J, Yang L, Chu J, Dong $S$, et al. The diagnostic value of long noncoding RNA MIR31HG and its role in esophageal squamous cell carcinoma. Life Sci. 2018;202(September 2017):124-30.

119 Zhang C, Wang C, Chen X, Yang C, Li K, Wang J, et al. Expression profile of MicroRNAs in serum: a fingerprint for esophageal squamous cell carcinoma. Clin Chem. 2010; 56(12):1871-9.

120 Zhang T, Wang Q, Zhao D, Cui Y, Cao B, Guo L, et al. The oncogenetic role of microRNA-31 as a potential biomarker in oesophageal squamous cell carcinoma. Clin Sci. 2011 Nov;121(10):437-47.

121 Wang B, Zhang Q. The expression and clinical significance of circulating microRNA-21 in serum of five solid tumors. J Cancer Res Clin Oncol. 2012;138(10):165966.

122 Takeshita N, Hoshino I, Mori M, Akutsu Y, Hanari N, Yoneyama Y, et al. Serum microRNA expression profile: MiR-1246 as a novel diagnostic and prognostic biomarker for oesophageal squamous cell carcinoma. $\mathrm{Br} \mathrm{J}$ Cancer. 2013;108(3):644-52.

123 Wu C, Wang C, Guan X, Liu Y, Li D, Zhou $\mathrm{X}$, et al. Diagnostic and prognostic implications of a serum miRNA panel in oesophageal squamous cell carcinoma. PLoS One. 2014;9(3):e92292-11.

124 Komatsu S, Ichikawa D, Takeshita H, Tsujiura M, Morimura R, Nagata $\mathrm{H}$, et al. Circulating microRNAs in plasma of patients with oesophageal squamous cell carcinoma. $\mathrm{Br} \mathrm{J}$ Cancer. 2011;105(1):104-11.

125 Hirajima S, Komatsu S, Ichikawa D, Takeshita $\mathrm{H}$, Konishi $\mathrm{H}$, Shiozaki A, et al. Clinical impact of circulating miR-18a in plasma of patients with oesophageal squamous cell carcinoma. Br J Cancer. 2013;108(9):18229.

126 Ferlay J, Steliarova-Foucher E, Lortet-Tieulent J, Rosso S, Coebergh JW, Comber H, et al. Cancer incidence and mortality patterns in Europe: estimates for 40 countries in 2012. Eur J Cancer. 2013;49(6):1374-403.

127 Chen $\mathrm{H}, \mathrm{Xu}$ J, Hong J, Tang R, Zhang X, Fang JY. Long noncoding RNA profiles identify five distinct molecular subtypes of colorectal cancer with clinical relevance. Mol Oncol. 2014;8(8):1393-403.

128 Wang R, Du L, Yang X, Jiang X, Duan W, Yan S, et al. Identification of long noncoding RNAs as potential novel diagnosis and prognosis biomarkers in colorectal cancer. J Cancer Res Clin Oncol. 2016;142(11):2291301.

129 Alaiyan B, Ilyayev N, Stojadinovic A, Izadjoo M, Roistacher M, Pavlov V, et al. Differential expression of colon cancer associated transcript1 (CCAT1) along the colonic adenoma-carcinoma sequence. BMC Cancer. 2013;13:196.

130 Ramzy I, Hasaballah M, Marzaban R, Shaker O, Soliman ZA. Evaluation of microRNAs29a, 92a and 145 in colorectal carcinoma as candidate diagnostic markers: an Egyptian pilot study. Clin Res Hepatol Gastroenterol. 2015;39(4):508-15.

131 Shaker OG, Ali MA, Ahmed TI, Zaki OM, Ali DY, Hassan EA, et al. Association between LINC00657 and miR-106a serum expression levels and susceptibility to colorectal cancer, adenomatous polyposis, and ulcerative colitis in Egyptian population. IUBMB Life. 2019;71(9):1322-35.

132 Zekri AR, Youssef AS, Lotfy MM, Gabr R, Ahmed OS, Nassar A, et al. Circulating serum miRNAs as diagnostic markers for colorectal cancer. PLoS One. 2016;11(5): e0154130-14.

133 Kanaan Z, Rai SN, Eichenberger MR, Roberts H, Keskey B, Pan J, et al. Plasma MiR-21: a potential diagnostic marker of colorectal cancer. Ann Surg. 2012;256(3):544-51.

134 Kanaan Z, Roberts H, Eichenberger MR, Billeter A, Ocheretner G, Pan J, et al. A plasma MicroRNA panel for detection of colorectal adenomas: a step toward more precise screening for colorectal cancer. Ann Surg. 2013;258(3):400-8.

135 Carter JV, Galbraith NJ, Yang D, Burton JF, Walker SP, Galandiuk S. Blood-based microRNAs as biomarkers for the diagnosis of colorectal cancer: a systematic review and meta-analysis. Br J Cancer. 2017;116(6): 762-74.

136 He Y, Lin J, Kong D, Huang M, Xu C, Kim TK, et al. Current state of circulating microRNAs as cancer biomarkers. Clin Chem. 2015;61(9):1138-55.

137 Wang R, Wen H, Xu Y, Chen Q, Luo Y, Lin Y, et al. Circulating MicroRNAs as a novel class of diagnostic biomarkers in gastrointestinal tumors detection: a meta-analysis based on 42 articles. PLoS One. 2014;9(11):e113401.

138 Link A, Kupcinskas J. MicroRNAs as noninvasive diagnostic biomarkers for gastric cancer: current insights and future perspectives. World J Gastroenterol. 2018;24(30): 3313-29.

139 Wan JCM, Massie C, Garcia-Corbacho J, Mouliere F, Brenton JD, Caldas C, et al. Liquid biopsies come of age: towards implementation of circulating tumour DNA. Nat Rev Cancer. 2017 Apr;17(4):223-38.

140 Volik S, Alcaide M, Morin RD, Collins C. Cell-free DNA (cfDNA): clinical significance and utility in cancer shaped by emerging technologies. Mol Cancer Res. 2016; 14(10):898-908.
141 Normando SRC, de Oliveira Delgado P, Rodrigues AKSB, David Filho WJ, Fonseca FLA, Cruz FJSM, et al. Circulating free plasma tumor DNA in patients with advanced gastric cancer receiving systemic chemotherapy. BMC Clin Pathol. 2018; 18(1):2-7.

142 Lapin M, Oltedal S, Tjensvoll K, Buhl T, Smaaland R, Garresori H, et al. Fragment size and level of cell-free DNA provide prognostic information in patients with advanced pancreatic cancer. J Transl Med. 2018;16(1):300-10.

143 Qian C, Ju S, Qi J, Zhao J, Shen X, Jing R, et al. Alu-based cell-free DNA: a novel biomarker for screening of gastric cancer. Oncotarget. 2017;8(33):54037-45.

144 Hsieh CC, Hsu HS, Chang SC, Chen YJ. Circulating cell-free DNA levels could predict oncological outcomes of patients undergoing esophagectomy for esophageal squamous cell carcinoma. Int J Mol Sci. 2016 17(12):2131.

145 Bedin C, Enzo MV, Del Bianco P, Pucciarelli S, Nitti D, Agostini M. Diagnostic and prognostic role of cell-free DNA testing for colorectal cancer patients. Int J Cancer. 2017;140(8):1888-98.

146 Lan YT, Chen MH, Fang WL, Hsieh CC, Lin $\mathrm{CH}$, Jhang $\mathrm{FY}$, et al. Clinical relevance of cell-free DNA in gastrointestinal tract malignancy. Oncotarget. 2017;8(2):3009-17.

147 Huang A, Zhang X, Zhou SL, Cao Y, Huang XW, Fan J, et al. Plasma circulating cell-free DNA integrity as a promising biomarker for diagnosis and surveillance in patients with hepatocellular carcinoma. J Cancer. 2016; 7(13):1798-803.

148 Tan P, Yeoh KG. Genetics and molecular pathogenesis of gastric adenocarcinoma. Gastroenterology. 2015;149(5):1153-e3.

149 Wijnhoven BP, Tilanus HW, Dinjens WN Molecular biology of Barrett's adenocarcinoma. Ann Surg. 2001;233(3):322-37.

150 Rumiato E, Boldrin E, Malacrida S, Realdon S, Fassan M, Morbin T, et al. Detection of genetic alterations in cfDNA as a possible strategy to monitor the neoplastic progression of Barrett's esophagus. Transl Res. 2017;190:16-24.

151 Ueda M, Iguchi T, Masuda T, Nakahara Y, Hirata $\mathrm{H}$, Uchi R, et al. Somatic mutations in plasma cell-free DNA are diagnostic markers for esophageal squamous cell carcinoma recurrence. Oncotarget. 2016;7(38):6228091.

152 Luo H, Li H, Hu Z, Wu H, Liu C, Li Y, et al Noninvasive diagnosis and monitoring of mutations by deep sequencing of circulating tumor DNA in esophageal squamous cell carcinoma. Biochem Biophys Res Commun. 2016;471(4):596-602.

153 Hamakawa T, Kukita Y, Kurokawa Y, Miyazaki $\mathrm{Y}$, Takahashi $\mathrm{T}$, Yamasaki $\mathrm{M}$, et al. Monitoring gastric cancer progression with circulating tumour DNA. Br J Cancer. 2015; 112(2):352-6 
154 Kwak EL, Ahronian LG, Siravegna G, Mussolin B, Godfrey JT, Clark JW, et al. Molecular heterogeneity and receptor coamplification drive resistance to targeted therapy in MET-Amplified esophagogastric cancer. Cancer Discov. 2015;5(12):1271-81.

155 Azad TD, Chaudhuri AA, Fang P, Qiao Y, Esfahani MS, Chabon JJ, et al. Circulating tumor DNA analysis for detection of minimal residual disease after chemoradiotherapy for localized esophageal cancer. Gastroenterology. 2020;158(3):494-e6.

156 Kim YW, Kim YH, Song Y, Kim HS, Sim HW, Poojan S, et al. Monitoring circulating tumor DNA by analyzing personalized cancer-specific rearrangements to detect recurrence in gastric cancer. Exp Mol Med. 2019; 51(8):1.

157 Garcia-Fernandez N, Macher H, Rubio A, Jimenez-Arriscado P, Vernal-Bellido C, Bellido-Diaz ML. Detection of p53 Mutations in circulating DNA of transplanted hepatocellular carcinoma patients as a biomarker of tumor recurrence. Adv Exp Med Biol. 2016; 924:25-8.

158 Shoda K, Ichikawa D, Fujita Y, Masuda K, Hiramoto H, Hamada J, et al. Monitoring the HER2 copy number status in circulating tumor DNA by droplet digital PCR in patients with gastric cancer. Gastric Cancer. 2017;20(1):126-35.

159 Aguilar-Mahecha A, Joseph S, Cavallone L, Buchanan M, Krzemien U, Batist G, et al. Precision medicine tools to guide therapy and monitor response to treatment in a HER-2+ gastric cancer patient: case report. Front Oncol. 2019;9(August):698.

160 Park KU, Lee HE, Nam SK, Nam KH, Park DJ, Kim HH, et al. The quantification of HER2 and MYC gene fragments in cell-free plasma as putative biomarkers for gastric cancer diagnosis. Clin Chem Lab Med. 2014 Jul;52(7):1033-40.

161 Lee JJ, Chu E. The role of predictive molecular biomarkers for the treatment of metastatic colorectal cancer. Curr Colorectal Cancer Rep. 2014;10(4):395-402.

162 Takai E, Totoki Y, Nakamura H, Morizane C, Nara S, Hama N, et al. Clinical utility of circulating tumor DNA for molecular assessment in pancreatic cancer. Sci Rep. 2015; 5:18425-10.

163 Kinugasa H, Nouso K, Miyahara K, Morimoto Y, Dohi C, Tsutsumi K, et al. Detection of K-ras gene mutation by liquid biopsy in patients with pancreatic cancer. Cancer. 2015;121(13):2271-80.

164 Thierry AR, Mouliere F, El Messaoudi S, Mollevi C, Lopez-Crapez E, Rolet F, et al. Clinical validation of the detection of KRAS and BRAF mutations from circulating tumor DNA. Nat Med. 2014;20(4):430-5.

165 Schell MJ, Yang M, Teer JK, Lo FY, Madan A, Coppola D, et al. A multigene mutation classification of 468 colorectal cancers reveals a prognostic role for APC. Nat Commun. 2016;7:11743-12.
166 Sausen M, Phallen J, Adleff V, Jones S, Leary RJ, Barrett MT, et al. Clinical implications of genomic alterations in the tumour and circulation of pancreatic cancer patients. Nat Commun. 2015;6(7686):7686.

167 Zill OA, Greene C, Sebisanovic D, Siew LM, Leng J, Vu M, et al. Cell-free DNA next-generation sequencing in pancreatobiliary carcinomas. Cancer Discov. 2015;5(10):10408.

168 Lan J, Lu Y, Guan Y, Chang L, Yu Z, Qian H. Identification of circulating tumor DNA using a targeted 545-gene next generation sequencing panel in patients with gastric cancer. Oncol Lett. 2020;19(3):2251-7.

169 Labgaa I, Villacorta-Martin C, D’Avola D, Craig AJ, Von Felden J, Martins-Filho SN, et al. A pilot study of ultra-deep targeted sequencing of plasma DNA identifies driver mutations in hepatocellular carcinoma. Oncogene. 2018;37(27):3740-52.

170 Fang WL, Lan YT, Huang KH, Liu CA, Hung YP, Lin $\mathrm{CH}$, et al. Clinical significance of circulating plasma DNA in gastric cancer. Int J Cancer. 2016;138(12):2974-83.

171 Sefrioui D, Sarafan-Vasseur N, Beaussire L, Baretti M, Gangloff A, Blanchard F, et al. Clinical value of chip-based digital-PCR platform for the detection of circulating DNA in metastatic colorectal cancer. Dig Liver Dis. 2015;47(10):884-90.

172 Bettegowda C, Sausen M, Leary RJ, Kinde I, Wang Y, Agrawal N, et al. Detection of circulating tumor DNA in early- and late-stage human malignancies. Sci Transl Med. 2014; 6(224):224ra24.

173 Taly V, Pekin D, Benhaim L, Kotsopoulos SK, Le Corre D, Li X, et al. Multiplex picodroplet digital PCR to detect KRAS mutations in circulating DNA from the plasma of colorectal cancer patients. Clin Chem. 2013; 59(12):1722-31.

174 Baumler A, Sperandio V. Interactions between the microbiota and pathogenic bacteria in the gut. Nature. 2016;535(7610):8593.

175 Bakken JS, Borody T, Brandt LJ, Brill JV, Demarco DC, Franzos MA, et al. Treating clostridium difficile infection with fecal microbiota transplantation. Clin Gastroenterol Hepatol. 2011;9(12):1044-9.

176 Khor B, Gardet A, Xavier RJ. Genetics and pathogenesis of inflammatory bowel disease. Nature. 2011;474(7351):307-17.

177 Balfour Sartor R, Wu GD. Roles for intestinal bacteria, viruses, and fungi in pathogenesis of inflammatory bowel diseases and therapeutic approaches. Gastroenterology. 2017;152(2):327-39.

178 Hedin CR, McCarthy NE, Louis P, Farquharson FM, McCartney S, Taylor K, et al. Altered intestinal microbiota and blood $\mathrm{T}$ cell phenotype are shared by patients with Crohn's disease and their unaffected siblings. Gut. 2014;63(10):1578-86.
179 Gevers D, Kugathasan S, Denson LA, Vázquez-Baeza Y, Van Treuren W, Ren B, et al. The treatment-naive microbiome in newonset Crohn's disease. Cell Host Microbe. 2014;15(3):382-92.

180 Halfvarson J, Brislawn CJ, Lamendella R, Vázquez-Baeza Y, Walters WA, Bramer LM, et al. Dynamics of the human gut microbiome in inflammatory bowel disease. Nat Microbiol. 2017;2(1):17004-48.

181 Nemoto H, Kataoka K, Ishikawa H, Ikata K Arimochi $\mathrm{H}$, Iwasaki T, et al. Reduced diversity and imbalance of fecal microbiota in patients with ulcerative colitis. Dig Dis Sci. 2012;57(11):2955-64.

182 Pascal V, Pozuelo M, Borruel N, Casellas F, Campos D, Santiago A, et al. A microbial signature for Crohn's disease. Gut. 2017;66(5): 813-22.

183 Hyams JS, Thomas SD, Haberman Y, Karns R, Schirmer M, Mo A, et al. Clinical and biological predictors of response to standardised paediatric colitis therapy: a Multicentre Inception Cohort Study. Lancet. 2019;393(10182):1708-20.

184 Ananthakrishnan AN, Luo C, Yajnik V, Khalili H, Garber JJ, Stevens BW, et al. Gut microbiome function predicts response to anti-integrin biologic therapy in inflammatory bowel diseases. Cell Host Microbe. 2017;21(5):603-e3.

185 Aden K, Rehman A, Waschina S, Pan WH, Walker A, Lucio M, et al. Metabolic functions of gut microbes associate with efficacy of tumor necrosis factor antagonists in patients with inflammatory bowel diseases. Gastroenterology. 2019;157(5):1279-e11.

186 Magnusson MK, Strid H, Sapnara M, Lasson A, Bajor A, Ung KA, et al. Anti-TNF therapy response in patients with ulcerative colitis is associated with colonic antimicrobial peptide expression and microbiota composition. J Crohns Colitis. 2016;10(8):943-52.

187 De Cruz P, Kang S, Wagner J, Buckley M, Sim WH, Prideaux L, et al. Association between specific mucosa-associated microbiota in Crohn's disease at the time of resection and subsequent disease recurrence: a pilot study. J Gastroenterol Hepatol. 2015;30(2):268-78.

188 Sokol H, Brot L, Stefanescu C, Auzolle C, Barnich N, Buisson A, et al. Prominence of ileal mucosa-associated microbiota to predict postoperative endoscopic recurrence in Crohn's disease. Gut. 2020;69(3):462-72.

189 Rajca S, Grondin V, Louis E, Vernier-Massouille G, Grimaud JC, Bouhnik Y, et al. Alterations in the intestinal microbiome (dysbiosis) as a predictor of relapse after infliximab withdrawal in Crohn's disease. Inflamm Bowel Dis. 2014;20(6):978-86.

190 Maharshak N, Ringel Y, Katibian D, Lundqvist A, Sartor RB, Carroll IM, et al. Fecal and mucosa-associated intestinal microbiota in patients with diarrhea-predominant irritable bowel syndrome. Dig Dis Sci. 2018; 63(7):1890-9. 
191 Staudacher HM, Whelan K. Altered gastrointestinal microbiota in irritable bowel syndrome and its modification by diet: probiotics, prebiotics and the low FODMAP diet. Proc Nutr Soc. 2016;75(3):306-18.

192 Jeffery IB, Quigley EM, Öhman L, Simrén M, O'Toole PW. The microbiota link to irritable bowel syndrome: an emerging story. Gut Microbes. 2012;3(6):572-6.

193 Hugerth LW, Andreasson A, Talley NJ, Forsberg AM, Kjellström L, Schmidt PT, et al. No distinct microbiome signature of irritable bowel syndrome found in a Swedish random population. Gut. 2020;69(6):107684.

194 De Martel C, Ferlay J, Franceschi S, Vignat J, Bray F, Forman D, et al. Global burden of cancers attributable to infections in 2008: a review and synthetic analysis. Lancet Oncol. 2012;13(6):607-15.

195 Wang F, Meng W, Wang B, Qiao L. Helicobacter pylori-induced gastric inflammation and gastric cancer. Cancer Lett. 2014;345(2): 196-202.

196 Coker OO, Dai Z, Nie Y, Zhao G, Cao L, Nakatsu G, et al. Mucosal microbiome dysbiosis in gastric carcinogenesis. Gut. 2018; 67(6):1024-32.

197 Wang T, Cai G, Qiu Y, Fei N, Zhang M, Pang $\mathrm{X}$, et al. Structural segregation of gut microbiota between colorectal cancer patients and healthy volunteers. ISME J. 2012;6(2):3209.

198 Goodwin AC, Destefano Shields CE, Wu S, Huso DL, Wu X, Murray-Stewart TR, et al. Polyamine catabolism contributes to enterotoxigenic bacteroides fragilis-induced colon tumorigenesis. Proc Natl Acad Sci U S A. 2011;108(37):15354-9.
199 Holt RA, Cochrane K. Tumor potentiating mechanisms of fusobacterium nucleatum, a multifaceted microbe. Gastroenterology. 2017;152(4):694-6.

200 Bullman S, Pedamallu CS, Sicinska E, Clancy TE, Cai D, Neuberg D, et al. Analysis of fusobacterium persistence and antibiotic response in colorectal cancer. Science. 2017; 358(6369):1443-8.

201 Chen Y, Lu Y, Ke Y, Li Y. Prognostic impact of the fusobacterium nucleatum status in colorectal cancers. Medicine. 2019;98(39): $1-7$.

202 Yu J, Feng Q, Wong SH, Zhang D, Liang QY, Qin Y, et al. Metagenomic analysis of faecal microbiome as a tool towards targeted noninvasive biomarkers for colorectal cancer. Gut. 2017;66(1):70-8.

203 Wong SH, Kwong TNY, Chow TC, Luk AKC, Dai RZW, Nakatsu G, et al. Quantitation of faecal fusobacterium improves faecal immunochemical test in detecting advanced colorectal neoplasia. Gut. 2017;66(8):14418.

204 Eklöf V, Löfgren-Burström A, Zingmark C, Edin S, Larsson P, Karling P, et al. Cancerassociated fecal microbial markers in colorectal cancer detection. Int J Cancer. 2017;141(12):2528-36.

205 Feng Q, Liang S, Jia H, Stadlmayr A, Tang L, Lan Z, et al. Gut microbiome development along the colorectal adenoma-carcinoma sequence. Nat Commun. 2015;6:6528.

206 Liang Q, Chiu J, Chen Y, Huang Y, Higashimori A, Fang J, et al. Fecal bacteria act as novel biomarkers for noninvasive diagnosis of colorectal cancer. Clin Cancer Res. 2017; 23(8):2061-70.
207 Puri P, Liangpunsakui S, Christensen JE, Shah V, Kamath P, Gores G, et al. The circulating microbiome signature and inferred functional metagenomics in alcoholic hepatitis. Hepatology. 2018;67(4):804-28.

208 Zhang Y, Zhao R, Shi D, Sun S, Ren H, Zhao $\mathrm{H}$, et al. Characterization of the circulating microbiome in acute-on-chronic liver failure associated with hepatitis B. Liver Int. 2019;39(7):1207-16.

209 Kajihara M, Koido S, Kanai T, Ito Z, Matsumoto Y, Takakura K, et al. Characterisation of blood microbiota in patients with liver cirrhosis. Eur J Gastroenterol Hepatol. 2019; 31(12):1577-83.

210 Cho EJ, Leem S, Kim SA, Yang J, Lee YB, Kim SS, et al. Circulating microbiota-based metagenomic signature for detection of hepatocellular carcinoma. Sci Rep. 2019;9(1): 1-8.

211 Poore GD, Kopylova E, Zhu Q, Carpenter C Fraraccio S, Wandro S, et al. Microbiome analyses of blood and tissues suggest cancer diagnostic approach. Nature. 2020 579(7800):567-74.

212 Gao S. Data analysis in single-cell transcriptome sequencing. Methods Mol Biol. 2018; 1754:311-26.

213 Wang Y, Navin NE. Advances and applications of single-cell sequencing technologies. Mol Cell. 2015 May;58(4):598-609.

214 Tang X, Huang Y, Lei J, Luo H, Zhu X. The single-cell sequencing: new developments and medical applications. Cell Biosci. 2019; 9(1):53.

215 Rantalainen M. Application of single-cell sequencing in human cancer. Brief Funct Genomics. 2018 Jul;17(4):273-82. 